\title{
Investigation into The First Anthrax Outbreak in A Cattle Farm in West Cameroon
}

\author{
Abel Wade* and Gaelle Kamdjo \\ Laboratoire National Veterinaries, Annex Yaoundé, Cameroon \\ *Corresponding author: Abel Wade, Laboratoire National Veterinaries, Annex Yaoundé, Cameroon
}

\begin{tabular}{l} 
ARTICLE INFO \\
\hline Received: March 09, 2019 \\
Published: 幽 March 15, 2019 \\
\hline Citation: Abel Wade, Gaelle Kamdjo. \\
Investigation into The First Anthrax \\
Outbreak in A Cattle Farm in West \\
Cameroon. Biomed J Sci \& Tech Res \\
16(1)-2019. BJSTR. MS.ID.002784.
\end{tabular}

ABSTRACT

Zoonotic diseases such as anthrax are major public health threads with high effect due to their toxins. In Cameroon, sporadic cases were reported only in the northern part (North, Far-North and Adamaoua regions) of the country until in 2015 when a case was reported in a cattle farm in Bangangté (West region of Cameroon), causing the sudden death of 4 out of 100 animals in a herd. Laboratory investigation using PCR and Sanga sequencing indicated that the bacterial strains were like those found in the Northern parts of Cameroon and other parts of Central and West Africa.

Keywords: Anthrax; Outbreak; Cattle; Cameroon

\section{Introduction}

Anthrax is a major zoonotic, acute spore-forming bacterial disease caused by Bacillus anthracis. The bacterium produces extremely potent toxins which are responsible for the ill effects with high mortality rate (CDC 2011). Anthrax spores are extremely resistant and survive for years in soil, or on wool or hair of infected animals so that if ingested or inhaled, transfer by flies' bites that have fed on an infected animal or carcass, or on entering through cuts in the skin, they can germinate and cause disease with possible death within 24 hours Barry et al. [1]. Human gets infected through indirect or direct contact by inhaling, touching, or ingesting Bacillus anthracis spores from meat of infected domestic or wildlife animal (OIE, 2008). The World Health Organization has estimated that $50 \mathrm{~kg}$ of $B$. anthracis released upwind of a population center of 500,000 could result in 95,000 deaths and 125,000 hospitalizations (WHO 2008). Subsequent to the 1979 Sverdlovsk incident, human cases were seen up to $4 \mathrm{~km}$ from the source, but dead sheep were noted $64 \mathrm{~km}$ downwind, and in villages between [2]. In Cameroon, sporadic cases of anthrax have been reported in domestic animals in the North, Far-North and Adamaoua regions only. This case report describes the first outbreak of anthrax in cattle farm in the west region of Cameroon.

\section{Case Report}

In February 2015, cases of sudden mortalities were reported in a cattle farm in Bangangte locality in the West region of Cameroon. Four animals (4\%) died out of a 100. Clinical signed observed on carcasses included hemorrhage with uncoagulated blood oozing from the anus, nostrils and mouth. The blood had a black coloration. The cattle keeper reported the cases to the veterinary services of the Ministry of Livestock, Fisheries and Animal Industries (MINEPIA). Mortalities occurred in two days (one evening and the next morning). Out of fear, those carcasses were left in-situ without action until the veterinarian arrived for investigation and care. Samples were collected and send to Laboratoire National Veterinaries (LANAVET) Annex in Yaoundé for analysis. Findings confirmed the presence of Bacillus anthracis in 7 out of 8 samples. Carcasses were deep burned and buried accordingly with the assistance of environmental health experts. Contact humans including population at risk were medically taken care at the regional hospital. No human case was confirmed. Soil samples on the site are being collected yearly and monitored for B. anthracis spores if any. Contact animals were kept isolated and samples for laboratory investigation. Farm and surrounding 
animals were immediately vaccinated against anthrax followed by a yearly program. This case has involved a multisectorial One Health approach for a successful management.

\section{Materials and Methods}

The field veterinary service of MINEPIA collected 4 samples of ear fragments and 4 swaps of running blood from the four dead animals and send on ice to LANAVET Annex in Yaoundé for laboratory analysis. We extracted DNA from those samples using Qiagen kit according to the manufacturer's protocol. Nucleic acid amplification in PCR was carried out in an total mix of 50ul each containing $25.5 \mu \mathrm{l}$ of molecular water, $5 \mu$ l of $10 \mathrm{x}$ buffer (Qiagen), $3 \mu \mathrm{l}$ of $25 \mathrm{mM} \mathrm{MgCl}{ }_{2}$, $4 \mu \mathrm{l}$ of $10 \mathrm{mM}$ dNTP, $4 \mu \mathrm{l}$ of each $5 \mu \mathrm{M}$ primer (Cap1234: CTG-AGCCAT-TAA-TCG-ATA-TG and Cap1301: TCC-CAC-TTA-CGT-AAT-CTGAG), $0.5 \mu \mathrm{l}$ of $5 / \mu \mathrm{L}$ Taq polymerase and $4 \mu \mathrm{l}$ of DNA. This mix was subjected to a cycling condition of $95^{\circ} \mathrm{C}$ for $5 \mathrm{~min}$, followed by 40 cycles of 30 seconds at $95^{\circ} \mathrm{C}, 30 \mathrm{sec}$ at $60^{\circ} \mathrm{C}$, then $72^{\circ} \mathrm{C}$ for 1 minute. The product was subjected to a final extension of 10 minutes at $72^{\circ} \mathrm{C}$. Positive PCR products observed under UV illumination following an electrophoresis were send to LGC genomics (Germany) for Sanger sequencing. Following the laboratory confirmation at LANAVET annex Yaoundé, contact animal in isolation were sampled for laboratory investigation including environmental samples (soil) were the carcasses buried. Similarly, samples from contact humans were also monitored for this bacterium

\section{Results and Discussion}

Findings from the gel-based PCR revealed the presence of approximatively 846 bp products in 3 and 4 tissue and blood samples respectively, corresponding to the Cap gene fragments of $B$. anthracis. This was the first report of anthrax case in this part of Cameroon. Similar cases were sporadically reported in

\section{ISSN: 2574-1241}

DOI: 10.26717/BJSTR.2019.16.002784

Abel Wade. Biomed J Sci \& Tech Res

This work is licensed under Creative Commons Attribution 4.0 License

Submission Link: https://biomedres.us/submit-manuscript.php the Adamaoua, North and Far-North regions only specially at the border of lack Chad basin. Nucleotide blast of gene sequences on NCBI (data not shown) showed that this outbreak was caused by the same source (same bacterial strain). Most importantly, the strain found in this outbreak was like those previously described by [2-4] and belong to clade $A \beta$ cluster of clade $D$, a common group of B. anthracis in west and central Africa. This may be as a result of animal introduction from the North or Far-North regions of Cameroon to this farm. Similar situations are observed when a disease carrier animal from infected area is introduce to a diseasefree farm [5,6]. The fact that cattle are transported these days from the North, Far-North and Adamaoua regions for slaughter or sell in the rest of the southern part of the country including Nigeria is a high risk for pathogen exchange and spread. Particularly that some of these animals are from republic of Chad or Sudan. Vaccination of that farm and surroundings was initiated immediately. Site monitoring for possible anthrax spores is still on.

\section{References}

1. Anthrax (malignant edema, wool sorters disease) (2011) Centers for Disease Control and Prevention (CDC).

2. L Barry Seltz, Leslie L Barton (2012) Kendig \& Chernick's Disorders of the Respiratory Tract in Children. In: L Barry Seltz, Leslie L Barton (Eds.), (8 ${ }^{\text {th }}$ Edn.).

3. Pilo P, Rossano A, Bamamga H, Abdoulkadiri S, Perreten V, et al. (2011) Bovine Bacillus anthracis in Cameroon. Applied and environmental microbiology 77(16): 5818-5821.

4. http://www.oie.int/en/animal-health-in-the-world/animal-diseases/ Anthrax/

5. (2008) Anthrax in Humans and Animals. (4 $4^{\text {th }}$ edn.), World Health Organization, Anthrax in humans. Geneva, USA.

6. Martin E Hugh Jones (2019) Overview of Anthrax. MSD and the MSD Veterinary Manual.

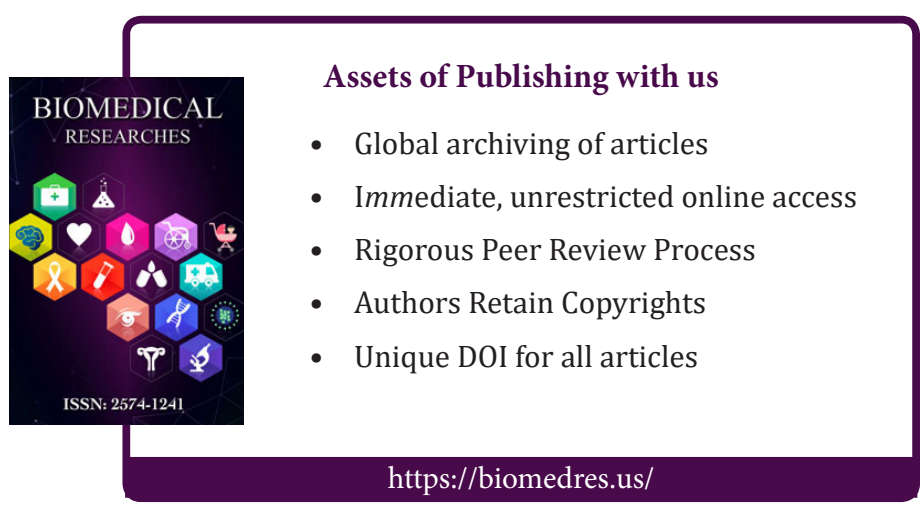

